\title{
A Method for Monitoring Macromolecular Synthesis in Filamentous Fungi and its Use to Study Control of Nucleic Acid Synthesis in Aspergillus nidulans
}

\author{
By HERBERT N. ARST, JR* AND CLAUdIO SCAZZOCCHIO \\ Department of Genetics, University of Cambridge, Downing Street, Cambridge CB2 $3 E H$
}

(Received 24 October 1979)

\begin{abstract}
A method is described for measuring the syntheses of macromolecules in the filamentous fungus Aspergillus nidulans. It involves growth of mycelium on small filter papers in the presence of radioactively labelled L-leucine to monitor total protein synthesis, and hence growth, and following the incorporation of differently labelled D-uridine (to measure nucleic acid synthesis) or L-leucine (to measure protein synthesis) under various conditions such as starvation for a metabolite or the presence of an inhibitor. Comparison of ${ }^{3} \mathrm{H} /{ }^{14} \mathrm{C}$ or ${ }^{14} \mathrm{C} /{ }^{3} \mathrm{H}$ labelling ratios (depending on the labelling combination used) shows the effects of the treatments on nucleic acid or protein synthesis. The method allows large numbers of measurements to be made and enables economical use of radioisotopes. Results are presented to show that, under the labelling conditions used, uridine is incorporated mainly into stable RNA. The method is used to demonstrate probable stringent control of stable RNA synthesis in $A$. nidulans and that inhibitors of protein synthesis such as cycloheximide and anisomycin also inhibit stable RNA synthesis. In contrast, starvation for meso-inositol affects nucleic acid synthesis much more strongly than it affects protein synthesis.
\end{abstract}

\section{INTRODUCTION}

A number of years ago, we developed a method for monitoring the synthesis of nucleic acids and other macromolecules in the ascomycete Aspergillus nidulans. This method and certain of our results were described at several meetings (published only as abstracts: Arst \& Scazzocchio, 1971, 1972a, $b$ ). As our research interests changed, we discontinued this series of experiments late in 1971. Nevertheless, even now full publication of the method and our results will be beneficial for at least two reasons. Firstly, the method deserves a wider availability. Although we used it mainly to look at control of nucleic acid synthesis in $A$. nidulans, it can be adapted for the study of the synthesis of other macromolecules and for use in other filamentous micro-organisms. Secondly, $A$. nidulans has proved to be one of the most suitable lower eukaryotes for a variety of biochemical and genetical investigations, including characterization of its RNA polymerases (Stunnenberg et al., 1979), and interest in the organism continues to grow (see, for example, the series of papers in Smith \& Pateman, 1977). Despite the passage of time, certain aspects of the methodology and the results remain novel and of potential use in further studies with this or other organisms.

Present address: Department of Genetics, Ridley Building, The University, Newcastle upon Tyne NE1 7RU.

$\$$ Present address: Department of Biology, University of Essex, Wivenhoe Park, Colchester CO4 3 SQ. 


\section{METHODS}

Strains. Construction of $A$. nidulans strains for this work was by standard genetic techniques (Pontecorvo et al., 1953; Clutterbuck, 1974). Genotypes of strains used for each experiment are given in the Table legends. All markers used are in standard use (Clutterbuck, 1974; Palmer \& Cove, 1975). All strains carry the L-leucine auxotrophy $l u A l$ and the pyrimidine auxotrophy pyrD23. Use was also made of the adenine auxotrophy $\operatorname{adH} 23$, the L-arginine auxotrophy $\arg B 2$, the choline auxotrophy choA1, the mutation leading to loss of choline- $O$-sulphatase $\operatorname{csuA6}$, the L-histidine auxotrophy his $C 38$, the meso-inositol auxotrophy inoB2, the L-methionine auxotrophy methG1, the L-proline auxotrophy proA6, and the putrescine auxotrophy $p u A 2$. In addition, some strains carried biA1 (biotin auxotrophy), $w A 2$ or $w A 5$ (white conidial colour), or $y A 2$ (yellow conidial colour).

Chemicals. L- $\left[4,5-{ }^{3} \mathrm{H}\right]$ Leucine, $\mathrm{L}-\left[\mathrm{U}-{ }^{14} \mathrm{C}\right]$ leucine, $\mathrm{D}-\left[5-{ }^{3} \mathrm{H}\right]$ uridine, $\mathrm{D}-\left[6{ }^{3} \mathrm{H}\right]$ uridine and $\mathrm{D}-\left[2-{ }^{14} \mathrm{C}\right]$ uridine were purchased from The Radiochemical Centre, Amersham. Cycloheximide, actinomycin D and emetine (hydrochloride) were purchased from Koch-Light, Calbiochem and Sigma, respectively. $\alpha$-Amanitin was generously provided by Professor Th. Wieland (Heidelberg, F.R.G.), anisomycin by Pfizer (Sandwich, Kent) and rifampicin by Gruppo Lepetit Laboratories (Milan, Italy). All other chemicals were of reagent grade where possible.

Measurement of nucleic acid synthesis. Suspensions of approximately $10^{4}$ conidiospores $\mathrm{ml}^{-1}$ were prepared in unsupplemented liquid minimal medium (Cove, 1966) containing $0 \cdot 1 \%(\mathrm{v} / \mathrm{v})$ Tween 80 . Sterile Whatman no. 1 filter papers $(2 \cdot 0 \mathrm{~cm}$ diam.) were briefly but thoroughly immersed in conidiospore suspensions and placed on solid minimal medium (Cove, 1966) containing $1 \%(\mathrm{w} / \mathrm{v}) \mathrm{D}$-glucose as carbon source and supplemented with (final concentrations) $10 \mu \mathrm{g}$ biotin $\mathrm{l}^{-1}, 10 \mathrm{~mm}-\mathrm{NaNO}_{3}$ (as nitrogen source), $10 \mathrm{mm-D}-\mathrm{mridine}$ and $1 \mathrm{~mm}-\mathrm{L}-$ leucine, either labelled with ${ }^{3} \mathrm{H}$ in positions 4 and 5 at a final specific activity of $500 \mathrm{mCi} \mathrm{mol}^{-1}$ $\left(18.5 \mathrm{GBq} \mathrm{mol}^{-1}\right)$ or uniformly labelled with ${ }^{14} \mathrm{C}$ at a final specific activity of $50 \mathrm{mCi} \mathrm{mol}^{-1}\left(1 \cdot 85 \mathrm{GBq} \mathrm{mol}^{-1}\right)$ or, in the experiment shown in Table $5,12.5 \mathrm{mCi} \mathrm{mol}^{-1}\left(462.5 \mathrm{MBq} \mathrm{mol}^{-1}\right)$. In addition, where appropriate to genotype, solid media were supplemented with (final concentrations) $100 \mu \mathrm{M}$-adenine, $1 \mathrm{~mm}$-L-arginine (hydrochloride), $10 \mu \mathrm{M}$-choline (chloride), $250 \mu \mathrm{M}-\mathrm{L}$-histidine, $22 \mu \mathrm{M}$-meso-inositol, $250 \mu \mathrm{M}-\mathrm{L}-\mathrm{methionine}$, $1 \mathrm{mM}-\mathrm{L}-$ proline, or $8 \mu \mathrm{M}$ (limiting) or $20 \mathrm{mM}$ (excess) putrescine (dihydrochloride). Filter papers were individually numbered with pencil before sterilization and the position of each was marked on the bottom of the Petri dish. Filter papers were handled with sterile forceps, and generally 12 were placed on a standard (90 mm diam.) Petri dish without touching each other. Growth then took place on the solid medium for $21 \mathrm{~h}$ at $37^{\circ} \mathrm{C}$. If starvation for a metabolite (adenine, L-arginine, choline, L-histidine, meso-inositol, Lmethionine, L-proline or putrescine) was desired, it was invariably necessary to commence the starvation during the $21 \mathrm{~h}$ growth period on solid medium. In this case an appropriate number of plates with solid medium lacking the metabolite in question were poured before adding the metabolite and pouring the remainder of the plates. This ensured that the solid media were identical (particularly with regard to specific activity of isotope) except for the one metabolite. An appropriate number of filter papers was then transferred to the solid medium lacking the metabolite for the final 2 or $4 \mathrm{~h}$ (as indicated in the Tables or Table legends) of the $21 \mathrm{~h}$ period. The Petri dishes containing the solid media were incubated for an additional day at $37{ }^{\circ} \mathrm{C}$ to enable eventual contamination to be detected. As the positions of filter papers had been marked, a contaminated filter paper was easily identified (in any case, in our experiments considerably less than $0 \cdot 1 \%$ of filter papers were contaminated)

Once removed from solid medium, the mycelium-containing filter papers were washed by successive transfer through three $250 \mathrm{ml}$ portions of unsupplemented liquid minimal medium at $37^{\circ} \mathrm{C}$ (thus avoiding both osmotic and temperature shock) and thoroughly blotted. The filter papers were then placed, mycelium down (as they grew mainly on the side exposed to the air whilst on the solid media), in individual round receptacles $(2.2 \mathrm{~cm}$ internal diam.) containing $800 \mu \mathrm{l}$ of liquid medium. These receptacles were made by heating about $1 \mathrm{~cm}$ lengths of sterile Pyrex tubing and inserting them severally into sterile heavy plastic Petri dishes such that a watertight seal was made. The liquid medium was a minimal medium (Cove, 1966) containing $1 \%(\mathrm{w} / \mathrm{v}) \mathrm{D}$-glucose as carbon source and supplemented with (final concentrations) $10 \mu \mathrm{g}$ biotin $1^{-1}, 10 \mathrm{~mm}-\mathrm{NaNO}_{3}$ (as nitrogen source), $1 \mathrm{~mm}$-L-leucine with the same isotope label at the same final specific activity as in the solid medium, and $100 \mu \mathrm{M}$-D-uridine, either labelled with ${ }^{3} \mathrm{H}$ (when $\mathrm{L}-\left[{ }^{[4} \mathrm{C}\right] l$ leucine was used) in the 5 or the 6 (as indicated) position at a final specific activity of $30 \mathrm{Ci} \mathrm{mol}^{-1}\left(1 \cdot 11 \mathrm{TBq} \mathrm{mol}^{-1}\right)$ or with ${ }^{14} \mathrm{C}$ (when $\mathrm{L}-\left[{ }^{3} \mathrm{H}\right]$ leucine was used) in the 2 position at a final specific activity of $2 \mathrm{Ci} \mathrm{mol}^{-1}\left(74 \mathrm{GBq} \mathrm{mol}^{-1}\right)$. Other supplements at the concentrations as listed above for the solid medium and various inhibitors were included in the liquid medium as indicated in the Tables and Table legends. Except for the experiment shown in Table 6 where incubation times (at $37^{\circ} \mathrm{C}$ ) are indicated, filter papers were incubated at $37{ }^{\circ} \mathrm{C}$ for $2 \mathrm{~h}$. They were then transferred to ice-cold $10 \%(\mathrm{w} / \mathrm{v})$ trichloroacetic acid and washed with more ice-cold $10 \%$ trichloroacetic acid followed by ice-cold, distilled water on Hirsch funnels under vacuum. The filter papers 
were then placed in scintillation vials and dried for $30 \mathrm{~min}$ at $90^{\circ} \mathrm{C}$. After cooling, $10 \mathrm{ml}$ scintillant $[4 \mathrm{~g}$ 2,5-diphenyloxazole and $40 \mathrm{mg}$ 1,4-di-2-(5-phenyloxazolyl)benzene per litre toluene] was added, and vials were counted using the automatic setting for ${ }^{3} \mathrm{H}$ and ${ }^{14} \mathrm{C}$ double labelling in a Packard 3375 Tri-Carb liquid scintillation counter.

Measurement of protein synthesis. This was identical to the method for measurement of nucleic acid synthesis except that in the liquid medium the uridine was unlabelled whereas the L-leucine was labelled both with ${ }^{3} \mathrm{H}$, in positions 4 and 5 , at a specific activity of $500 \mathrm{mCi} \mathrm{mol}^{-1}\left(18.5 \mathrm{GBq} \mathrm{mol}^{-1}\right)$, and with ${ }^{14} \mathrm{C}$, uniformly distributed, at a final specific activity of $50 \mathrm{mCi} \mathrm{mol}^{-1}\left(1.85 \mathrm{GBq} \mathrm{mol}^{-1}\right)$. To follow the effects of a treatment in parallel on nucleic acid and protein syntheses, all other supplements were added to the liquid medium which was then divided into aliquots to which either $\mathrm{D}-\left[2-{ }^{14} \mathrm{C}\right]$ uridine or $\mathrm{L}-\left[\mathrm{U}-{ }^{14} \mathrm{C}\right] \mathrm{leucine}$ was added.

\section{RESULTS AND DISCUSSION}

\section{Salient features of the method for measuring macromolecular synthesis}

In vivo measurement of many processes in a filamentous organism such as Aspergillus nidulans is more difficult than in unicellular organisms because changes in turbidity of the culture medium cannot be used effectively to measure growth. In compensation, however, many filamentous organisms can grow with attachment to a solid support such as a filter paper. This enables easy transfer from one growth medium to another (using sterile forceps) with intervening washing, if necessary. Although growth must commence on a solid medium so that it is confined to one side of the filter paper (the side exposed to the air), filter papers can then be transferred either to another solid medium or to a liquid medium. Growth can be monitored by including a radioactively labelled precursor of a macromolecule in all media. The use of an amino acid necessary for protein synthesis is an obvious choice because most in vitro measurements are reported relative to the amount of soluble protein in cell extracts. The use of strains auxotrophic for the amino acid increases labelling efficiency and ensures that labelling is an accurate measure of protein synthesis and therefore growth. L-Leucine was chosen because (1) a suitable auxotrophy, luAl (Clutterbuck, 1974), is available, (2) it is a frequent constituent of proteins, (3) it is catabolically rather inert (i.e. amongst the amino acids, it is one of the poorest nitrogen or carbon sources for $A$. nidulans), thus ensuring high specificity and efficiency of labelling and minimizing the danger of formation of volatile radioactive catabolites, and (4) it is commercially available labelled with ${ }^{3} \mathrm{H}$ or ${ }^{14} \mathrm{C}$ at reasonable cost.

The inclusion of a second, differently labelled compound in one or more subsequent media enables synthesis of another macromolecule to be followed relative to total protein synthesis/growth. For counting purposes, ${ }^{3} \mathrm{H}$ and ${ }^{14} \mathrm{C}$ form a convenient labelling combination, as used here. For these experiments, the second labelled compound was present in only the final medium (a liquid medium). Thus mycelia grown under identical conditions initially could be subjected to different treatments during which synthesis of a particular class of macromolecules relative to total protein synthesis/growth could be compared. The criteria for choosing the second labelled precursor are largely the same as those outlined above for the choice of L-leucine. To follow the effects of various treatments on protein synthesis, differently labelled L-leucine can be used (so that the final medium contains both ${ }^{3} \mathrm{H}$ - and ${ }^{14} \mathrm{C}$-labelled L-leucine), and thus no second amino acid auxotrophy is necessary for labelling purposes. To monitor nucleic acid synthesis, labelled D-uridine was chosen, and these experiments utilized strains carrying the pyrimidine auxotrophy pyrD23 (Palmer \& Cove, 1975) in addition to $u A 1$. Uridine is catabolically inert in $A$. nidulans, commercially available labelled with ${ }^{3} \mathrm{H}$ or ${ }^{14} \mathrm{C}$, and supplements $p y r$ auxotrophs of $A$. nidulans at lower concentrations than uracil. Recently, studies elsewhere have shown that both RNA and DNA can be labelled more efficiently in vivo in a $p y r$ strain of $A$. nidulans than in a prototroph and that labelled uridine is incorporated more efficiently than labelled uracil (Zinchenko et al., 1978). Labelled adenine can also be used for labelling nucleic acids very efficiently (Kessel \& Rosenberger, 1968, and our unpublished results). However, adenine labelling 
necessitates, in addition to an ad auxotrophy, a mutational block in purine catabolism which does not result in accumulation of a toxic intermediate of purine degradation (see Darlington \& Scazzocchio, 1967). An $h x B$ mutation, resulting in loss of the two hypoxanthine-oxidizing enzymes now designated purine hydroxylases I and II (Scazzocchio \& Darlington, 1968; Scazzocchio et al., 1973; Lewis et al., 1978), meets these requirements. Care must also be taken to avoid adenine labelled such that the label will be retained during histidine biosynthesis (Orr \& Rosenberger, 1976). $\left[8-{ }^{14} \mathrm{C}\right]-$ and $\left[8-{ }^{3} \mathrm{H}\right]$ adenine meet this requirement and are commercially available.

Unfortunately, DNA cannot be labelled specifically in A. nidulans because catabolism of thymine and thymidine (reviewed by O'Donovan \& Neuhard, 1970) results in labelling of RNA as well (Zinchenko et al., 1978). Moreover, wild-type A. nidulans lacks thymidine kinase and therefore cannot incorporate exogenously supplied thymidine into DNA (Grivell \& Jackson, 1968). Nevertheless, comparison of results obtained using D-[5- $\left.{ }^{3} \mathrm{H}\right]$ uridine and D-[6- $\left.{ }^{3} \mathrm{H}\right]$ uridine can be used to estimate the relative contribution of DNA synthesis to total nucleic acid synthesis (see below).

The method enables economical use of radioisotopes. For example, 12 of the $2 \mathrm{~cm}$ diam. filter papers used here fit on to a standard $(90 \mathrm{~mm})$ plate of solid medium, and $800 \mu \mathrm{l}$ of liquid medium per filter paper is adequate for incubation. At the conclusion of experiments, extraction with ice-cold $10 \%(\mathrm{w} / \mathrm{v})$ trichloroacetic acid removes both non-specifically adsorbed labelled compounds and pools of small molecules containing the labels. Comparison of ${ }^{3} \mathrm{H} /{ }^{14} \mathrm{C}$ or ${ }^{14} \mathrm{C} /{ }^{3} \mathrm{H}$ labelling ratios (depending on the labelling combination used) provides a relative measure of the effects of various treatments on macromolecular synthesis. Complete details of the protocol used here are given in Methods. The method should be adaptable to monitoring synthesis of macromolecules other than proteins and nucleic acids and possibly also to following synthesis of macromolecular structures such as membranes or the cell wall. This method has been used to monitor the effects of methylammonium on protein synthesis in wild-type and methylammonium-resistant mutants of $A$. nidulans (Arst \& Page, 1973). A similar technique has been used for transport studies in $A$. nidulans (Arst \& Page, 1973; Bailey \& Arst, 1975; Arst \& Scazzocchio, 1975; Scazzocchio \& Arst, 1978). Filter papers have also been used as solid supports for cultures of Trichoderma viride (Gressel \& Galun, 1967).

\section{Examples of the effects of various treatments on nucleic acid synthesis}

Results in Tables 1 to 4 illustrate how the method can be used to follow the effects of various treatments on nucleic acid synthesis. For example, purine starvation, using a strain having a mutation blocking the biosynthesis of all purines (Foley et al., 1965), considerably reduced incorporation of labelled uridine (Table 1). It is possibly surprising that purine starvation did not altogether eliminate nucleic acid synthesis but this might be due to degradation of previously existing nucleic acid, which would make available sufficient purine nucleotides to support a low level of incorporation of the uridine label.

Results in Table 2 show that nucleic acid synthesis was inhibited by starvation for proline. Other results (not shown) using the same labelling combination showed that this was a general effect of amino acid starvation, as it was also elicited by deprivation of histidine, methionine or arginine. The efficiencies with which starvation for various amino acids inhibited nucleic acid synthesis appeared to differ widely, with histidine being the most efficient and methionine the least efficient in our experiments. These differences might reflect a variation in mechanisms of inhibition, but it seems more likely that they merely represent differences in the extents to which starvation was achieved. The efficiency of starvation will depend on pool sizes, extent of catabolism, and possibilities for synthesis by alternative pathways, and it is likely that comparable degrees of starvation for all amino acids cannot be achieved. In any case, it will be shown below that the labelled uridine was incorporated 


\section{Table 1. Effect of adenine starvation on nucleic acid synthesis}

A strain of genotype $y A 2 \mathrm{luAl}$ adH23 pyrD23 was labelled with L-[4,5-3 $\mathrm{H}]$ leucine to measure growth. Nucleic acid synthesis was followed using $\mathrm{D}-\left[2-{ }^{14} \mathrm{C}\right]$ uridine. ${ }^{14} \mathrm{C} /{ }^{3} \mathrm{H}$ ratios are the average of three determinations.

$\begin{array}{cccc}\begin{array}{c}\text { Duration of } \\ \text { adenine } \\ \begin{array}{c}\text { starvation on } \\ \text { solid medium }(\mathrm{h})\end{array}\end{array} & \begin{array}{c}\text { Adenine concn in } \\ \text { liquid medium } \\ (\mu \mathrm{M})\end{array} & \overbrace{}^{{ }^{14} \mathrm{C} /{ }^{3} \mathrm{H}} & \begin{array}{c}\text { Nucleic acid synthesis } \\ 0\end{array} \\ 0 & 100 & 1 \cdot 07 & 100 \\ 0 & 0 & 0 \cdot 241 & 22 \cdot 6 \\ 2 & 0 & 0 \cdot 155 & 14 \cdot 5 \\ 4 & 0 & 0 \cdot 156 & 14 \cdot 6\end{array}$

Table 2. Effect of L-proline starvation on nucleic acid synthesis

A strain of genotype $y A 2$ pro $A 6 \mathrm{l} U A 1$ pyrD23 was labelled with $\mathrm{L}-\left[4,5-{ }^{3} \mathrm{H}\right]$ leucine to measure growth. Nucleic acid synthesis was followed using $\mathrm{D}-\left[2-{ }^{14} \mathrm{C}\right]$ uridine. ${ }^{14} \mathrm{C} /{ }^{3} \mathrm{H}$ ratios are the average of three determinations.

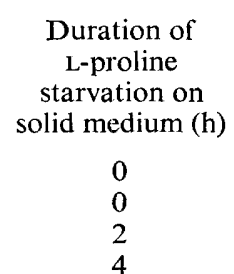

L-Proline concn
in liquid medium
$(\mathrm{mM})$
1
0
0
0

$\begin{array}{cc}{ }^{14} \mathrm{C} /{ }^{3} \mathrm{H} & \text { Nucleic acid synthesis } \\ 0.609 & 100 \\ 0.168 & 27 \cdot 6 \\ 0.060 & 9 \cdot 9 \\ 0.097 & 15 \cdot 9\end{array}$

Table 3. Effect of meso-inositol starvation on nucleic acid synthesis

A strain of genotype biA1 luA1 wA5 inoB2 pyrD23 was labelled with $\mathrm{L}-\left[4,5-{ }^{3} \mathrm{H}\right]$ leucine to measure growth. Nucleic acid synthesis was followed using $\mathrm{D}-\left[2-{ }^{14} \mathrm{C}\right]$ uridine. ${ }^{14} \mathrm{C} /{ }^{3} \mathrm{H}$ ratios are the average of three determinations.

$\begin{array}{cccc}\begin{array}{c}\text { Duration of } \\ \text { meso-inositol } \\ \text { starvation on } \\ \text { solid medium }(\mathrm{h})\end{array} & \begin{array}{c}\text { meso-Inositol } \\ \text { concn in liquid } \\ \text { medium }(\mu \mathrm{M})\end{array} & { }^{{ }^{14} \mathrm{C} /{ }^{3} \mathrm{H}} & \% \text { of control } \\ 0 & 22 & 1 \cdot 22 & 100 \\ 0 & 0 & 1 \cdot 02 & 83 \cdot 1 \\ 2 & 0 & 0 \cdot 914 & 74 \cdot 7 \\ 4 & 0 & 0 \cdot 283 & 23 \cdot 1\end{array}$

mainly into stable RNA, and therefore our results provide evidence for stringent control of stable RNA synthesis as has been demonstrated in the prokaryotes (reviewed by Edlin \& Broda, 1968). Amongst the fungi, the stringent response in Saccharomyces cerevisiae has been demonstrated by a number of groups (Wehr \& Parks, 1969; Roth \& Dampier, 1972; Gross \& Pogo, 1974; Wejksnora \& Haber, 1974; Kudrna \& Edlin, 1975; Oliver \& McLaughlin, 1977; Shulman et al., 1977; Warner \& Gorenstein, 1978; Ray \& Butow, 1979 a,b) and has also been demonstrated in Neurospora crassa (Somberg et al., 1966; Buckel \& Böck, 1973).

Results in Table 3 show inhibition of uridine incorporation by meso-inositol starvation. We were unable to demonstrate any effect of starvation for another component of phospholipids, choline, using a choAl strain, auxotrophic for choline (results not shown). However, choline auxotrophies are not manifested during the early stages of growth (Arst, 1968; Markham \& Bainbridge, 1979), and it is therefore possible that effective starvation for choline cannot be achieved during the relatively short period of the experiment.

Similarly there was no convincing effect of either putrescine starvation or excessive $(20 \mathrm{~mm})$ 
Table 4. Nucleic acid synthesis in the presence of cycloheximide or $\alpha$-amanitin

A strain of genotype biA1 luAl pyrD23 was labelled with $\mathrm{L}-\left[4,5-{ }^{3} \mathrm{H}\right]$ leucine to measure growth. Nucleic acid synthesis was followed using $\mathrm{D}-\left[2-{ }^{14} \mathrm{C}\right]$ uridine. ${ }^{14} \mathrm{C} /{ }^{3} \mathrm{H}$ ratios are the average of three determinations.

\begin{tabular}{|c|c|c|c|}
\hline \multirow{2}{*}{$\begin{array}{l}\text { Inhibitor present } \\
\text { in liquid medium }\end{array}$} & \multirow{2}{*}{$\begin{array}{l}\text { Inhibitor } \\
\text { concn } \\
\left(\mu \mathrm{g} \mathrm{ml}^{-1}\right)\end{array}$} & \multicolumn{2}{|c|}{ Nucleic acid synthesis } \\
\hline & & ${ }^{14} \mathrm{C} /{ }^{3} \mathrm{H}$ & $\%$ of control \\
\hline None & - & 0.656 & 100 \\
\hline Cycloheximide & $\begin{array}{r}1 \\
10 \\
100\end{array}$ & $\begin{array}{l}0 \cdot 509 \\
0 \cdot 196 \\
0 \cdot 213\end{array}$ & $\begin{array}{l}77 \cdot 6 \\
29 \cdot 9 \\
32 \cdot 5\end{array}$ \\
\hline$\alpha$-Amanitin & $\begin{array}{r}1 \cdot 67 \\
16.7 \\
167\end{array}$ & $\begin{array}{l}0.641 \\
0.656 \\
0.650\end{array}$ & $\begin{array}{c}97 \cdot 7 \\
100 \\
99 \cdot 1\end{array}$ \\
\hline
\end{tabular}

supplementation in a $p u A 2$ strain, auxotrophic for putrescine (results not shown). However, later, it was shown that putrescine is required during germination of conidiospores of $A$. nidulans but not during subsequent hyphal growth (Stevens, 1975; Stevens et al., 1976) so it is unlikely that, when measuring nucleic acid synthesis in mycelia, starvation for putrescine could have been effective. Winther \& Stevens (1978) demonstrated a requirement for putrescine for both protein and nucleic acid syntheses but only by starving conidiospores from the time of inoculation. As the method described here requires sufficient mycelial growth to ensure adherence to the filter papers, it is doubtful whether it could be used in conjunction with putrescine starvation from the time of inoculation.

Results in Table 4 show that nucleic acid synthesis was inhibited by cycloheximide. Cycloheximide is an effective inhibitor of protein synthesis in A. nidulans (Cybis \& Weglenski, 1972; Winther \& Stevens, 1978) and there is presumptive evidence that the basis of its toxicity in vivo is due to its interaction with cytoplasmic ribosomes (Waldron \& Roberts, $1974 a, b)$. It is therefore likely that cycloheximide inhibition of nucleic acid synthesis is a consequence of its inhibition of protein synthesis. In contrast, neither $\alpha$-amanitin at concentrations as high as $167 \mu \mathrm{g} \mathrm{ml}^{-1}$ (Table 4) nor actinomycin D at $67 \mu \mathrm{g} \mathrm{ml}^{-1}$ (results not shown) inhibited nucleic acid synthesis. Conidiospores of $N$. crassa are impermeable to these inhibitors (Tisdale \& DeBusk, 1972) so the lack of inhibition might be a question of impermeability. However, Stunnenberg et al. (1979) have shown that even in vitro three RNA polymerases of $A$. nidulans are largely or completely insensitive to $\alpha$-amanitin.

\section{Preliminary characterization of the nucleic acids whose synthesis is measured by the method}

Results in Table 5 allow calculation of the contribution which DNA synthesis makes to total nucleic acid synthesis, as measured by the method under conditions of both normal growth and proline starvation. The details of the calculation are given in the Appendix, but the method is based on comparison of ${ }^{3} \mathrm{H} /{ }^{14} \mathrm{C}$ labelling ratios when parallel experiments are done using $\left[5-{ }^{3} \mathrm{H}\right]$ uridine and $\left[6-{ }^{3} \mathrm{H}\right]$ uridine at equal concentrations and specific activities. The ${ }^{3} \mathrm{H}$ in the 5 position of uridine is removed in the thymidylate synthetase-catalysed methylation of dUMP to form TMP. Hence (assuming the absence of further base modification), $\left[6-{ }^{3} \mathrm{H}\right]$ uridine labels all pyrimidine residues in both RNA and DNA whereas $\left[5-{ }^{3} \mathrm{H}\right]-$ uridine labels pyrimidine residues of RNA but only cytosine residues of DNA. The actual calculation requires an estimate of the pyrimidine content of the RNA labelled in the experiment as well as of the guanine plus cytosine content of the DNA labelled in the experiment. We were then able to calculate that under proline-sufficient conditions DNA accounts for about $13 \%$ of the total nucleic acid synthesis, whereas under proline-starvation the proportion of DNA rises to about $79 \%$. A cursory glance at Table 5 confirms the direction of this 
Table 5. Comparison of nucleic acid synthesis as monitored by $\left[5-{ }^{3} \mathrm{H}\right]$ uridine and $\left[6-{ }^{3} \mathrm{H}\right]$ uridine in cultures supplemented with or starved for L-proline

A strain of genotype $y A 2$ pro $A 6$ luA1 pyrD23 was labelled with L-[U-14 C]leucine to measure growth. Nucleic acid synthesis was followed using D- $\left[5-{ }^{3} \mathrm{H}\right]$ uridine or $\mathrm{D}-\left[6_{-}{ }^{3} \mathrm{H}\right]$ uridine at equal final specific activities. Non-supplemented cultures were starved for $2 \mathrm{~h}$ on solid medium lacking L-proline and then incubated in proline-free liquid medium. ${ }^{3} \mathrm{H} /{ }^{14} \mathrm{C}$ ratios are the average of three determinations.

$\begin{array}{cccc}\begin{array}{c}\text { Position of }{ }^{3} \mathrm{H} \\ \text { in uridine }\end{array} & \begin{array}{c}\text { Supplementation } \\ \text { with L-proline } \\ (1 \mathrm{mM})\end{array} & { }^{{ }^{3} \mathrm{H} /{ }^{14} \mathrm{C}} & \% \text { of control } \\ 5 & + & 266 & 100 \\ 5 & - & 8 \cdot 02 & 3 \cdot 0 \\ 6 & + & 285 & 100 \\ 6 & - & 12 \cdot 5 & 4 \cdot 4\end{array}$

Table 6. Effect of incubation time on cycloheximide inhibition of nucleic acid synthesis A strain of genotype biA1 luAl pyrD23 was labelled with L-[U-14C]leucine to measure growth. Nucleic acid synthesis was followed using $\mathrm{D}-\left[5-{ }^{3} \mathrm{H}\right]$ uridine. Where indicated, cycloheximide was added to the liquid medium at a final concentration of $10 \mu \mathrm{g} \mathrm{ml} \mathbf{l}^{-1} \cdot{ }^{3} \mathrm{H} /{ }^{14} \mathrm{C}$ ratios are the average of three determinations.

$\begin{array}{cccc}\begin{array}{c}\text { Duration of } \\ \text { incubation in } \\ \begin{array}{c}\text { liquid medium } \\ \text { (min) }\end{array}\end{array} & \overbrace{- \text { Cycloheximide }}{ }^{{ }^{3} \mathrm{H} /{ }^{14} \mathrm{C}}+\text { Cycloheximide } & \begin{array}{c}\% \text { inhibition by } \\ \text { cycloheximide }\end{array} \\ 0 & 0.368 & 0.382 & 0 \\ 10 & 0.586 & 0.546 & 6 \cdot 8 \\ 30 & 1.99 & 1.42 & 28.7 \\ 120 & 13.4 & 2.92 & 78.2\end{array}$

result because proline starvation has a slightly less drastic effect on the ${ }^{3} \mathrm{H} /{ }^{14} \mathrm{C}$ labelling ratio when the ${ }^{3} \mathrm{H}$ is in the 6 position than when it is in the 5 position. Grossman et al. (1969) have reported preferential synthesis of mitochondrial DNA in S. cerevisiae when protein synthesis is prevented, and replication of nuclear DNA in the same organism, once initiated, can proceed in the presence of cycloheximide (Williamson, 1973; Golombek et al., 1974).

Results in Table 6 show that the effect of cycloheximide on nucleic acid synthesis increased with the length of the uridine incorporation period. This indicates that the $2 \mathrm{~h}$ incorporation period used here monitors primarily stable nucleic acid synthesis. Thus we are looking mainly at the regulation of stable RNA synthesis.

A further point is to be noted from the comparison of Tables 5 and 6 with Tables 2 and 4, respectively. In each case, some of the results are derived from an experimental protocol which is virtually the same except that the labels have been reversed, so that ${ }^{3} \mathrm{H}$ incorporation monitors nucleic acid synthesis and ${ }^{14} \mathrm{C}$ incorporation measures growth for the experiments shown in Tables 5 and 6, whereas the reverse is true for the experiments shown in Tables 2 and 4. The substantial equivalence of results obtained with the two possible labelling configurations confirms the absence of labelling artefacts.

\section{Examples of effects of combinations of treatments on nucleic acid synthesis}

In the experiment shown in Table 7 , proline starvation and cycloheximide $\left(10 \mu \mathrm{g} \mathrm{ml}^{-1}\right)$ inhibited nucleic acid synthesis to about the same extent and the effects were neither additive nor cancelling.

Table 8 shows the results of an experiment in which proline starvation, cycloheximide and rifampicin in various combinations were used to inhibit nucleic acid synthesis. In contrast to the much more modest 11 to $15 \%$ inhibition of nucleic acid synthesis by $500 \mu \mathrm{g}$ 
Table 7. Effect of simultaneous proline starvation and cycloheximide treatment on nucleic acid synthesis

A strain of genotype $y A 2$ pro $A 6$ luA1 pyrD 23 was labelled with L-[U- $\left.{ }^{14} \mathrm{C}\right]$ leucine to measure growth. Nucleic acid synthesis was followed using $\mathrm{D}-\left[5-{ }^{3} \mathrm{H}\right]$ uridine. Non-supplemented cultures were starved for $2 \mathrm{~h}$ on solid medium lacking L-proline and then incubated in proline-free liquid medium. ${ }^{3} \mathrm{H} /{ }^{14} \mathrm{C}$ ratios are the average of ten determinations.

$\begin{array}{cccc}\begin{array}{c}\text { Supplementation } \\ \text { with L-proline } \\ (1 \mathrm{mM})\end{array} & \begin{array}{c}\text { Cycloheximide } \\ \text { concn in } \\ \text { liquid medium } \\ \left(\mu \mathrm{g} \mathrm{ml}^{-1}\right)\end{array} & { }^{{ }^{3} \mathrm{H} /{ }^{14} \mathrm{C}} & \text { Nucleic acid synthesis } \\ + & 0 & 29 \cdot 2 & \% \text { of control } \\ + & 10 & 4 \cdot 18 & 100 \\ - & 0 & 4 \cdot 66 & 16 \cdot 3 \\ - & 10 & 4 \cdot 02 & 14 \cdot 1\end{array}$

Table 8. Effects of various combinations of proline starvation, cycloheximide treatment and rifampicin treatment on nucleic acid synthesis

A strain of genotype $y A 2$ pro $A 6 l u A I$ pyrD 23 was labelled with L-[U- $\left.{ }^{14} \mathrm{C}\right]$ leucine to measure growth. Nucleic acid synthesis was followed using D-[5- $\left.{ }^{3} \mathrm{H}\right]$ uridine. Non-supplemented cultures were starved for $2 \mathrm{~h}$ on solid medium lacking L-proline and then incubated in proline-free liquid medium. ${ }^{3} \mathrm{H} /{ }^{14} \mathrm{C}$ ratios are the average of five determinations.

\begin{tabular}{|c|c|c|c|c|}
\hline \multirow{2}{*}{$\begin{array}{l}\text { Supplementation } \\
\text { with L-proline } \\
(1 \mathrm{~mm})\end{array}$} & \multirow{2}{*}{$\begin{array}{l}\text { Cycloheximide } \\
\text { concn in } \\
\text { liquid medium } \\
\left(\mu \mathrm{g} \mathrm{ml}^{-1}\right)\end{array}$} & \multirow{2}{*}{$\begin{array}{l}\text { Rifampicin concn } \\
\text { in liquid medium } \\
\left(\mu \mathrm{g} \mathrm{ml}^{-1}\right)\end{array}$} & \multicolumn{2}{|c|}{ Nucleic acid synthesis } \\
\hline & & & ${ }^{3} \mathrm{H} /{ }^{14} \mathrm{C}$ & $\%$ of control \\
\hline+ & 0 & 0 & $23 \cdot 1$ & 100 \\
\hline+ & 10 & 0 & 4.03 & $17 \cdot 4$ \\
\hline+ & 0 & 500 & $11 \cdot 0$ & $47 \cdot 6$ \\
\hline+ & 10 & 500 & $4 \cdot 36$ & $18 \cdot 9$ \\
\hline- & 0 & 0 & 3.97 & $17 \cdot 2$ \\
\hline- & 10 & 0 & $2 \cdot 78$ & $12 \cdot 0$ \\
\hline- & 0 & 500 & $1 \cdot 40$ & $6 \cdot 5$ \\
\hline- & 10 & 500 & $3 \cdot 46$ & $15 \cdot 0$ \\
\hline
\end{tabular}

rifampicin $\mathrm{ml}^{-1}$ found in two previous experiments (results not shown), this same concentration of rifampicin inhibited nucleic acid synthesis by more than $50 \%$ in this experiment. The reason(s) for this discrepancy is unknown. As a different strain was used for this experiment, it is conceivable that an unidentified genetic difference affecting, for example, cell permeability to rifampicin is responsible. It is worth noting that, in combination with amphotericin B (which presumably aids its penetration through membranes), rifampicin is a potent inhibitor of RNA synthesis and growth in S. cerevisiae (Medoff et al., 1972; Battaner \& Kumar, 1974) and in the yeast phase of Histoplasma capsulatum (Kobayashi et $a l ., 1972)$. In any case, rifampicin inhibition here appears additive in its effect with proline starvation but not with cycloheximide treatment. Moreover, cycloheximide treatment negates the additivity of rifampicin treatment with proline starvation.

\section{Comparison of the effects of various treatments on nucleic acid and protein syntheses}

Results in Table 9 show that proline starvation reduced nucleic acid and protein syntheses to rather similar extents, whereas results in Table 10 show that inositol starvation preferentially affected nucleic acid synthesis. The effects of inositol starvation are of particular interest because they lead to 'inositol-less death', a phenomenon which has been intensively studied in N. crassa and S. cerevisiae (Strauss, 1958; Shatkin \& Tatum, 1961; Sullivan \& DeBusk, 1973; Keith et al., 1977; Henry et al., 1977; Hanson \& Brody, 1979). In S. cerevisiae, inositol starvation ultimately terminates macromolecular synthesis, and the results 


\section{Table 9. Effects of L-proline starvation on protein and nucleic acid syntheses}

A strain of genotype $y A 2$ pro $A 6$ luA1 pyrD23 was labelled with $\mathrm{L}-\left[4,5-{ }^{3} \mathrm{H}\right]$ leucine to measure growth. Nucleic acid synthesis was followed using $\mathrm{D}-\left[2-{ }^{14} \mathrm{C}\right]$ uridine, and protein synthesis was followed using L-[U-14C]leucine. Non-supplemented cultures were starved for $2 \mathrm{~h}$ on solid medium lacking $\mathrm{L}$-proline and then incubated in proline-free liquid medium. ${ }^{14} \mathrm{C} /{ }^{3} \mathrm{H}$ ratios are the average of four determinations.

Supplementation with L-proline (1 mM)

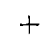

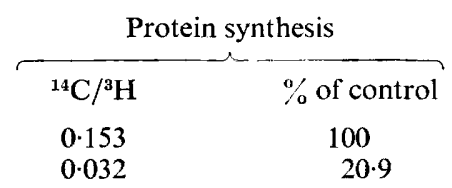

Nucleic acid synthesis

\begin{tabular}{|c|c|}
\hline${ }^{14} \mathrm{C} /{ }^{3} \mathrm{H}$ & $\%$ of contro \\
\hline $\begin{array}{l}1 \cdot 11 \\
0 \cdot 199\end{array}$ & $\begin{array}{l}100 \\
17.9\end{array}$ \\
\hline
\end{tabular}

Table 10. Effects of meso-inositol starvation on protein and nucleic acid syntheses

A strain of genotype biAl luAl wA5 inoB2 pyrD23 was labelled with $\mathrm{L}-\left[4,5-{ }^{3} \mathrm{H}\right]$ leucine to measure growth. Nucleic acid synthesis was followed using $\mathrm{D}-\left[2-{ }^{14} \mathrm{C}\right]$ uridine, and protein synthesis was followed using L-[U- $\left.{ }^{14} \mathrm{C}\right]$ leucine. Non-supplemented cultures were starved for $4 \mathrm{~h}$ on solid medium lacking meso-inositol and then incubated in inositol-free liquid medium. ${ }^{14} \mathrm{C} /{ }^{3} \mathrm{H}$ ratios are the average of four determinations.

Supplementation with meso-inositol

$$
(22 \mu \mathrm{M})
$$$$
+
$$

Protein synthesis

$\begin{array}{cc}{ }^{14} \mathrm{C} /{ }^{3} \mathrm{H} & \% \text { of control } \\ 0.196 & 100 \\ 0.176 & 89.8\end{array}$

Nucleic acid synthesis

$\begin{array}{cc}{ }^{14} \mathrm{C} /{ }^{3} \mathrm{H} & \% \text { of control } \\ 1.17 & 100 \\ 0.412 & 35.3\end{array}$

Table 11. Effects of anisomycin on protein and nucleic acid syntheses

A strain of genotype $y A 2$ proA6 luA1 pyr D23 was labelled with $\mathrm{L}-\left[4,5-{ }^{3} \mathrm{H}\right]$ leucine to measure growth. Nucleic acid synthesis was followed using $\mathrm{D}-\left[2-{ }^{14} \mathrm{C}\right]$ uridine, and protein synthesis was followed using L-[U- $\left.{ }^{14} \mathrm{C}\right]$ leucine. All media contained $1 \mathrm{~mm}-\mathrm{L}$-proline to supplement proA6. ${ }^{14} \mathrm{C} /{ }^{3} \mathrm{H}$ ratios are the average of four determinations.

Anisomycin concn in liquid medium $\left(\mu \mathrm{g} \mathrm{ml}^{-1}\right)$

0
100
333
1000
2000

Protein synthesis

$\begin{array}{cc}{ }^{14} \mathrm{C} /{ }^{3} \mathrm{H} & \% \text { of control } \\ 0.157 & 100 \\ 0.112 & 71.3 \\ 0.013 & 8.1 \\ 0.003 & 1.9 \\ 0.002 & 1.4\end{array}$

Nucleic acid synthesis

$\begin{array}{cc}{ }^{14} \mathrm{C} /{ }^{3} \mathrm{H} & \% \text { of control } \\ 0.973 & 100 \\ 0.752 & 77 \cdot 3 \\ 0 \cdot 404 & 41 \cdot 5 \\ 0.258 & 26.5 \\ 0.239 & 24.5\end{array}$

Table 12. Effects of emetine on protein and nucleic acid syntheses

A strain of genotype $y$ A2 proA6 luA1 pyrD23 was labelled with L-[4,5- $\left.{ }^{3} \mathrm{H}\right]$ leucine to measure growth. Nucleic acid synthesis was followed using $\mathrm{D}-\left[2-{ }^{14} \mathrm{C}\right]$ uridine, and protein synthesis was followed using $\mathrm{L}-\left[\mathrm{U}-{ }^{14} \mathrm{C}\right]$ leucine. All media contained $1 \mathrm{~mm}-\mathrm{L}-$ proline to supplement pro $A 6 .{ }^{14} \mathrm{C} /{ }^{3} \mathrm{H}$ ratios are the average of four determinations.

Emetine concn in liquid medium $\left(\mu \mathrm{g} \mathrm{ml}^{-1}\right)$

0
1
10
100
1000

Protein synthesis

$\begin{array}{cc}{ }^{14} \mathrm{C} /{ }^{3} \mathrm{H} & \% \text { of control } \\ 0.263 & 100 \\ 0.239 & 90.9 \\ 0.239 & 90.9 \\ 0.215 & 81 \cdot 7 \\ 0.201 & 76.4\end{array}$

Nucleic acid synthesis

$\begin{array}{cc}{ }^{14} \mathrm{C} /{ }^{3} \mathrm{H} & \% \text { of control } \\ 1.21 & 100 \\ 1.15 & 95 \cdot 7 \\ 1.17 & 96.9 \\ 1.06 & 87.3 \\ 0.949 & 78.7\end{array}$


suggest that RNA synthesis is affected slightly earlier than either protein or DNA synthesis (Henry et al., 1977). Just as no effect of choline starvation on nucleic acid synthesis in a choAl strain could be detected (see above), neither was there any effect on protein synthesis (results not shown). In the case of protein synthesis, the experiment was performed using a strain which carried, in addition to $\operatorname{choA1}$, csuA6, leading to loss of choline- $O$-sulphatase (Arst, 1971; Gravel, 1976), as well as using a choAl csuA ${ }^{+}$strain. csuA6 would have prevented release of choline from endogenous choline- $O$-sulphate, a fungal storage product (see Arst, 1971).

Results in Table 11 show that whilst preferentially affecting protein synthesis, anisomycin (see Grollman \& Huang, 1973) strongly inhibited nucleic acid synthesis as well. Emetine, another inhibitor of eukaryotic protein synthesis (Grollman \& Huang, 1973), was rather ineffective but inhibited protein and nucleic acid syntheses to similar extents (Table 12).

\section{APPENDIX}

The use of parallel experiments with $\left[5-{ }^{3} \mathrm{H}\right]$ uridine and $\left[6{ }^{3} \mathrm{H}\right]$ uridine to estimate the contribution of DNA synthesis to total nucleic acid synthesis

Suppose that $x$ nucleotides be incorporated into DNA containing $m$ fraction of thymine (and hence $\frac{1}{2}-m$ fraction of cytosine) and $y$ nucleotides be incorporated into RNA containing $n$ fraction of pyrimidines. Then the proportion of nucleotides incorporated into DNA is given by $x /(x+y)$.

Let $A$ be the amount of $\left[5-{ }^{3} \mathrm{H}\right]$ uridine incorporated per unit growth and $B$ be the amount of $\left[6-{ }^{3} \mathrm{H}\right]$ uridine incorporated per unit growth. Then (assuming pyrimidine base modification in positions 5 and 6 is quantitatively negligible), if $\left[5^{3} \mathrm{H}\right]-$ and $\left[6-{ }^{3} \mathrm{H}\right]$ uridine are added in identical, parallel experiments at equal concentrations and specific activities and can be incorporated into nucleic acids with equal efficiencies (i.e. no isotope effects), they will have the same labelling constant $k$ and

Subtracting (2) from (1):

$$
\begin{aligned}
& \mathrm{k} B=n y+\frac{1}{2} x \\
& \mathrm{k} A=n y+\left(\frac{1}{2}-m\right) x
\end{aligned}
$$

Substituting (4) in (1):

or

$$
\begin{aligned}
& \mathrm{k}(B-A)=m x \\
& x=\mathrm{k}(B-A) / m
\end{aligned}
$$

Then

$$
\text { or } \quad y=\mathrm{k}[(2 m-1) B+A] / 2 m n
$$

As cytoplasmic rRNA of $A$. nidulans contains approximately $50 \%$ pyrimidines (Verma et al., 1971), a reasonable estimate for $n$ would be $\frac{1}{2}$. Averaging the published values for the guanine plus cytosine content of $A$. nidulans DNA (Dutta et al., 1967; Storck \& Alexopoulos, 1970) gives approximately $50 \%$ so that $m$ is about 1. Thus for $A$. nidulans:

$$
x /(x+y)=2(B-A) / B
$$

For the proline-sufficient cultures, $B=285$ and $A=266$ (Table 5), and therefore DNA accounts for approximately $13 \%$ of total nucleic acid synthesis. For the proline-starved cultures, $B=12.5$ and $A=8.02$, and therefore DNA accounts for approximately $79 \%$ of total nucleic acid synthesis.

At the time when this work was carried out, we were supported by a grant from the Science Research Council to David Cove. We are very grateful to David Cove for useful discussions and for providing facilities for this work and to David Leaford for technical assistance. We would also like to thank Esra Galun for suggestions related to the development of the method and Michael Winther for critically reading the manuscript. 


\section{REFERENCES}

ARST, H. N., JR (1968). Genetic analysis of the first steps of sulphate metabolism in Aspergillus nidulans. Nature, London 219, 268-270.

ARsT, H. N., JR (1971). Mutants of Aspergillus nidulans unable to use choline- $O$-sulphate. Genetical Research 17, 273-277.

Arst, H. N., JR \& PAGE, M. M. (1973). Mutants of Aspergillus nidulans altered in the transport of methylammonium and ammonium. Molecular and General Genetics 121, 239-245.

ARst, H. N. \& ScAzzocchio, C. (1971). RNA synthesis in Aspergillus nidulans. Heredity 26, 346.

Arst, H. N. \& Scazzocchio, C. (1972a) Control of nucleic acid synthesis in Aspergillus nidulans. Biochemical Journal 127, 18P.

Arst, H. N. \& SCazzocchio, C. (1972b). Control of nucleic acid synthesis in Aspergillus nidulans. Heredity 29, 131.

Arst, H. N., JR \& Scazzocchio, C. (1975). Initiator constitutive mutation with an 'up-promoter' effect in Aspergillus nidulans. Nature, London 254, 31--34.

Bailey, C. \& ARst, H. N., JR (1975). Carbon catabolite repression in Aspergillus nidulans. European Journal of Biochemistry 51, 573-577.

Battaner, E. \& Kumar, B. V. (1974). Rifampin: inhibition of ribonucleic acid synthesis after potentiation by amphotericin B in Saccharomyces cere. visiae. Antimicrobial Agents and Chemotherapy 5, 371-376.

Buckel, P. \& Böck, A. (1973). Lack of accumulation of unusual guanosine nucleotides upon amino acid starvation of two eukaryotic organisms. Biochimica et biophysica acta 324, 184-187.

Clutterbuck, A. J. (1974). Aspergillus nidulans. In Handbook of Genetics, vol. I, pp. 447-510. Edited by R. C. King. New York: Plenum Press.

Cove, D. J. (1966). The induction and repression of nitrate reductase in the fungus Aspergillus nidulans. Biochimica et biophysica acta 113, 51-56.

Cybis, J. \& Weglenski, P. (1972). Arginase induction in Aspergillus nidulans. The appearance and decay of the coding capacity of messenger. European Journal of Biochemistry 30, 262-268.

Darlington, A. J. \& Scazzocchio, C. (1967). Use of analogues and the substrate-sensitivity of mutants in analysis of purine uptake and breakdown in Aspergillus nidulans. Journal of Bacteri$\operatorname{olog} y$ 93, 937-940.

DutTa, S. K., Richman, N., Woodward, V. W. \& Mandel, M. (1967). Relatedness among species of fungi and higher plants measured by DNA hybridization and base ratios. Genetics 57, 719-727.

EdLiN, G. \& BropA, P. (1968). Physiology and genetics of the 'ribonucleic acid control' locus in Escherichia coli. Bacteriological Reviews 32, 206226.

Fgley, J. M., Giles, N. H. \& Roberts, C. F. (1965). Complementation at the adenylosuccinase locus in Aspergillus nidulans. Genetics 52, 1247-1263.

Golombek, J., Wolf, W. \& Wintersberger, E. (1974). DNA synthesis and DNA-polymerase activity in synchronized yeast cells. Molecular and General Genetics 132, 137-145.

Gravel, R. A. (1976). Choline- $O$-sulphate utiliza- tion in Aspergillus nidulans. Genetical Research 28, 261-276.

Gressel, J. \& Galun, E. (1967). Morphogenesis in Trichoderma: photoinduction and RNA. Developmental Biology 15, 575-598.

GrivelL, A. R. \& JACKSON, J. F. (1968). Thymidine kinase: evidence for its absence from Neurospora crassa and some other micro-organisms, and the relevance of this to the specific labelling of deoxyribonucleic acid. Journal of General Microbiology. 54, 307-317.

Grollman, A. P. \& Huang, M. T. (1973). Inhibitors of protein synthesis in eukaryotes: tools in cell research. Federation Proceedings 32, 1673-1678.

Gross, K. J. \& PoGo, A. O. (1974). Control mechanism of ribonucleic acid synthesis in eukaryotes. The effect of amino acid and glucose starvation and cycloheximide on yeast deoxyribonucleic acid-dependent ribonucleic acid polymerases. Journal of Biological Chemistry 249, 568-576.

Grossman, L. I., Goldring, E. S. \& Marmur, J. (1969). Preferential synthesis of yeast mitochondrial DNA in the absence of protein synthesis. Journal of Molecular Biology 46, 367-376.

Hanson, B. \& Brody, S. (1979). Lipid and cell wall changes in an inositol-requiring mutant of Neurospora crassa. Journal of Bacteriology 138, 461-466.

Henry, S. A., Atkinson, K. D., Kolat, A. I. \& Culbertson, M. R. (1977). Growth and metabolism of inositol-starved Saccharomyces cerevisiae. Journal of Bacteriology 130, 472-484.

Keith, A. D., Pollard, E. C., Snipes, W., Henry, S. A. \& Culbertson, M. R. (1977). Inositol-less death in yeast results in simultaneous increase in intracellular viscosity. Biophysical Journal 17, 205-212.

Kessel, M. \& Rosenberger, R. F. (1968). Regulation and timing of deoxyribonucleic acid synthesis in hyphae of Aspergillus nidulans. Journal of Bacteriology 95, 2275-2281.

Kobayashi, G. S., Medoff, G., Schlessinger, D., Kwan, C. N. \& Musser, W. E. (1972). Amphotericin B potentiation of rifampicin as an antifungal agent against the yeast phase of Histoplasma capsulatum. Science 177, 709-710.

KudRnA, R. \& EDlin, G. (1975). Nucleotide pools and regulation of ribonucleic acid synthesis in yeast. Journal of Bacteriology 121, 740-742.

Lewis, N. J., Hurt, P., Sealy-Lewis, H. M. \& SCAZzocCHIO, C. (1978). The genetic control of the molybdoflavoproteins in Aspergillus nidulans. IV. A comparison between purine hydroxylase I and II. European Journal of Biochemistry 91, 311-316.

MarkhaM, P. \& Bainbridge, B. W. (1979). Characterization of a new choline locus in Aspergillus nidulans and its significance for choline metabolism. Genetical Research 32, 303-310.

Medoff, G., Kobayashi, G. S., Kwan, C. N., SChlessinger, D. \& Venkov, P. (1972). Potentiation of rifampicin and 5-fluorocytosine as antifungal antibiotics by amphotericin B. Proceedings of the National Academy of Sciences of the United States of America 69, 196-199. 
O'Donovan, G. A. \& Neuhard, J. (1970). Pyrimidine metabolism in micro-organisms. Bacteriological Reviews 34, 278-343.

Oliver, S. G. \& Mclaughlin, C. S. (1977). The regulation of RNA synthesis in yeast. I. Starvation experiments. Molecular and General Genetics 154, 145-153.

OrR, E. \& Rosenberger, R. F. (1976). Initial characterization of Aspergillus nidulans mutants blocked in the nuclear replication cycle. Journal of Bacteriology 126, 895-902.

Palmer, L. M. \& Cove, D. J. (1975). Pyrimidine biosynthesis in Aspergillus nidulans. Isolation and preliminary characterization of auxotrophic mutants. Molecular and General Genetics 138, 243-255.

Pontecorvo, G., Roper, J. A., Hemmons, L. A., Macdonald, K. D. \& Bufton, A. W. J. (1953). The genetics of Aspergillus nidulans. Advances in Genetics 5, 141-238.

RaY, D. B. \& Butow, R. A. (1979a). Regulation of mitochondrial ribosomal RNA synthesis in yeast. I. In search of a relaxation of stringency. Molecular and General Genetics 173, 227-238.

RAY, D. B. \& Butow, R. A. (1979b). Regulation of mitochondrial ribosomal RNA synthesis in yeast. II. Effects of temperature sensitive mutants defective in cytoplasmic protein synthesis. Molecular and General Genetics 173, 239-247.

Roth, R. M. \& DAmpier, C. (1972). Dependence of ribonucleic acid synthesis on continuous protein synthesis in yeast. Journal of Bacteriology 109, 773-779.

Scazzocchio, C. \& Arst, H. N., JR (1978). The nature of an initiator constitutive mutation in Aspergillus nidulans. Nature, London 274, 177-179.

Scazzocchio, C. \& Darlington, A. J. (1968). The induction and repression of the enzymes of purine breakdown in Aspergillus nidulans. Biochimica et biophysica acta 166, 557-568.

Scazzocchio, C., Holl, F. B. \& Foguelman, A. I. (1973). The genetic control of molybdoflavoproteins in Aspergillus nidulans. Allopurinolresistant mutants constitutive for xanthine dehydrogenase. European Journal of Biochemistry $36,428-445$.

Shatkin, A. J. \& Tatum, E. L. (1961). The relationship of m-inositol to morphology in Neurospora crassa. American Journal of Botany 48, 760-771.

Shulman, R. W., Sripati, C. E. \& Warner, J. R. (1977). Noncoordinated transcription in the absence of protein synthesis in yeast. Journal of Biological Chemistry 252, 1344-1349.

Smith, J. E. \& Pateman, J. A. (editors) (1977). Genetics and Physiology of Aspergillus. London: Academic Press.

Somberg, E. W., Salmon, B. J. \& Davis, F. F. (1966). Some effects of methionine starvation on a methionine auxotroph of Neurospora crassa. Biochimica et biophysica acta 129, 419-421.

STEVENS, L. (1975). Ornithine decarboxylase in germinating conidia of Aspergillus nidulans. FEBS Letters 59, 80-82.
Stevens, L., McKinnon, I. M. \& Winther, M. (1976). Polyamine and ornithine metabolism during the germination of conidia of Aspergillus nidulans. Biochemical Journal 158, 235-241.

Storck, R. \& Alexopoulos, C. J. (1970). Deoxyribonucleic acid of fungi. Bacteriological Reviews 34, 126-154.

Strauss, B. S. (1958). Cell death and 'unbalanced growth' in Neurospora. Journal of General Microbiology 18, 658-669.

StunNenberG, H. G., WenneKes, L. M. J. \& Van DEN BRoEK, H. W. J. (1979). RNA polymerase from the fungus Aspergillus nidulans. Large-scale purification of DNA-dependent RNA polymerase I (or A). European Journal of Biochemistry 98, 107-119.

Sullivan, J. L. \& DeBusk, A. G. (1973). Inositolless death in Neurospora and cellular ageing. Nature New Biology 243, 72-74.

Tisdale, J. H. \& DeBusk, A. G. (1972). Permeability problems encountered when treating conidia of Neurospora crassa with RNA synthesis inhibitors. Biochemical and Biophysical Research Communications 48, 816-822.

Verma, I. M., Edelman, M. \& Littauer, U. Z. (1971). A comparison of nucleotide sequences from mitochondrial and cytoplasmic ribosomal RNA of Aspergillus nidulans. European Journal of Biochemistry 19, 124-129.

Waldron, C. \& Roberts, C. F. (1974a). Coldsensitive mutants in Aspergillus nidulans. I. Isolation and general characterisation. Molecular and General Genetics 134, 99-113.

Waldron, C. \& Roberts, C. F. (1974b). Coldsensitive mutants in Aspergillus nidulans. II. Mutations affecting ribosome production. Molecular and General Genetics 134, 115-132.

WARNeR, J. R. \& GorensteIn, C. (1978). Yeast has a true stringent response. Nature, London 275 , 338-339.

Wehr, C. T. \& Parks, L. W. (1969). Macromolecular synthesis in Saccharomyces cerevisiae in different growth media. Journal of Bacteriology 98, 458-466.

WeJksnora, P. J. \& HABER, J. E. (1974). Methioninedependent synthesis of ribosomal ribonucleic acid during sporulation and vegetative growth of Saccharomyces cerevisiae. Journal of Bacteriology 120, 1344-1355.

Williamson, D. H. (1973). Replication of the nuclear genome in yeast does not require concomitant protein synthesis. Biochemical and Biophysical Research Communications 52, 731-740.

Winther, M. \& Stevens, L. (1978). Polyamine stimulation of in vivo rates of macromolecular synthesis in a putrescine auxotroph of Aspergillus nidulans. FEBS Letters 85, 229-232.

Zinchenko, V. B., Groshev, B. V. \& Kameneva, S. V. (1978). Use of a pyrimidine-dependent mutant for effective labelling of the DNA of Aspergillus nidulans. Microbiology, USSR (English translation) 47, 851-854. 